\title{
Classification of Construction Firms in Turkey by Using Miles and Snow's Typology
}

\author{
Aynur Kazaz ${ }^{1}$, Bayram Er ${ }^{1}$, Serdar Ulubeyli² ${ }^{2}$ B. Ezgi Ozdemir ${ }^{1}$ \\ ${ }^{1}$ Akdeniz University \\ 07058, Antalya, Turkey \\ E-mail.akazaz@akdeniz.edu.tr,bayramer@akdeniz.edu.tr,burcuezgiozdemir@hotmail.com \\ ${ }^{2}$ Bulent Ecevit University \\ 67100, Zonguldak, Turkey \\ E-mail.serdar.ulubeyli@karaelmas.edu.tr
}

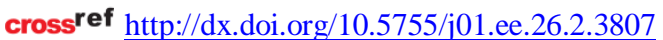

\begin{abstract}
Although strategic management is not common among construction firms, it was argued that construction firms develop strategies to maintain in the competitive environment and that they can be categorized according to their strategies, even if they are not managed formally. Because construction firms' strategies are specific and they are unwilling to share them, it is difficult to determine these strategies clearly. In this regard, instead of determining their strategies, it was aimed to categorize them according to Miles and Snow's Strategy Typology. Toward this aim, 50 large-scale construction firms in Turkey were surveyed by a questionnaire. In this context, Miles and Snow's Typology was first investigated, and possible goals of each strategic group were determined. Then, a SWOT analysis was applied to firms to determine their current positions in the market, and their primary goals were asked. The results revealed that construction firms with the same goals show similar characteristics and thus can be categorized as defenders, prospectors, and analyzers, according to Miles and Snow's Typology.
\end{abstract}

Keywords: Miles and Snow's Strategy Typology, strategy, strategic management, strategic planning, SWOT analysis.

\section{Introduction}

Construction industry is related with many other industries and encloses different professions. Most construction firms offer services in different scopes with different specialties. In addition, globalization increases international contracting activities, and thus, the industry becomes more complex. This diversification and complexity lead to increases in uncertainties and in risks associated with the domain of construction.

The industry is also very sensitive to internal and external factors such as equity, experience, technology, economics, and politics. These factors may influence firms positively or negatively (Danosh, 2005). Therefore, construction firms should properly determine their visions and the associated strategies to attain these visions. In order to determine the right strategies, the top management should correctly evaluate strengths and weaknesses as well as opportunities and threats introduced by the market.

(Betts \& Ofori, 1992) stated that the long-term survival of large-scale firms depends on effective strategic management. However, according to (Venegas \& Alarcon, 1997), the economic theory that the strategic management literature is based on is not easy to implement in the construction industry. (Male \& Stocks, 1991) stated that organizational structures that are developed based on the strategy theory are useful for firms operating in the manufacturing industry. Therefore, it can be asserted that current strategic management practices may not be appropriate to construction firms. However, especially in the last two decades, it has become widespread among large-scale construction firms to spare more resources to the strategic thinking procedure (Price et al., 2003).

Based on these core arguments, in this study it was assumed that, even if strategic management may be neglected by many construction firms, it still does not mean that they do not have suitable strategies. This is because, whether extensively planned or not, all companies have a strategic perspective which is analogous to the personality of an individual (Dikmen \& Birgonul, 2003). The primary goal of a firm is to make profit, and this firm follows a different way to achieve this goal. Some firms keep customer satisfaction forefront while others try to minimize risks or maximize profits.

Since construction firms are not participative in sharing their strategies, in this study, instead of determining these strategies, it was aimed to determine the strategy groups of firms by using Miles and Snow's Strategy Typology. For this purpose, four main goals were first identified for each strategy group by addressing Miles and Snow's Typology. Second, main goals of 50 large-scale construction firms operating in Turkey were asked. Then, a SWOT analysis was applied to firms to determine their current positions in the market. Finally, the main goals and SWOT analysis results of each firm were compared. The results showed that firms with same main goals have similar current positions and thus can be grouped in the same strategy group. Since firms in the same group show similar strategic tendencies, it will be easier to develop new strategies for construction firms which can adapt the strategic management philosophy to their organizations. In this context, this paper was set out as follows: a literature review to investigate the position of 
strategic management in the construction industry, illustration of the methodological framework, results of the given questionnaire and their discussion, and finally the conclusion.

\section{Strategic Management in Construction}

Although strategic management is not common among construction firms, it has attracted the attention of many authors so far. In other words, several researches have been conducted to date about this specific topic.

(Betts \& Ofori, 1992) pointed out the difficulties of strategic planning in construction and introduced some solutions to apply it in construction firms. Similarly, (Price \& Newson, 2003) identified some paradoxes of strategic management and proposed some recommendations to handle them. (Cheah \& Garvin, 2004) focused on six strategy fields (i.e., financial strategy, technology strategy, information technology strategy, human resource strategy, marketing strategy and business strategy) together with operational strategy in strategic management. (Dikmen \& Birgonul, 2003) analyzed strategic perspectives of construction firms in Turkey. Strategic performances of international construction firms were evaluated by (Cheah $e t$ al., 2004). Some tools for strategic management were introduced by (Naaranoja et al., 2007). Similarly, (Warszawski, 1996) introduced a methodology for strategic planning and some strategies for construction firms.

In addition to these aforementioned studies, some researchers also examined strategic management practices in different countries. (Price et al., 2003) revealed that construction firms in the UK usually utilize strategic management in an informal way. Only large-scale firms have formal strategic management practices whereas middle-size firms use such practices when they are necessary (Price et al., 2003). Studies conducted in Ghana and Malaysia also attained similar results with those in the UK (Danosh, 2005; Abu Bakar et al., 2011). In these countries, only large-scale construction firms formally utilize strategic management. Unlike these studies, (Kazaz \& Ulubeyli, 2009) found out that most of construction firms in Turkey do not have a strategic management culture, after surveying 52 large-scale construction firms.

Among others, only (Warszawski, 1996) introduced some construction specific strategies while other researchers proposed some generic strategies based on Porter's (1980) strategy classification composed of cost leadership, differentiation, and focus. None of researchers tried to group the firms according to their strategic tendencies. The main aim of developing suitable strategies is to survive in the market in today's highly competitive business environment. In order to identify appropriate strategies, firms should first determine their current positions in the market by evaluating their organizational strengths and weaknesses together with opportunities and threats introduced by the market. In fact, their current positions indicate a specific strategy group they belong to. Therefore, determining a firm's strategy group will help them to develop strategies and thereby to adapt the concept "strategic management" to their organizations.

In this study, it was argued that, regardless of formal or informal, every construction firm has a strategy and this strategy is strongly related with its current position. All firms develop some strategies to achieve some goals, and these goals are highly correlated with both internal (strengths and weaknesses) and external (opportunities and threats) factors. In other words, two assumptions were made:

(i) Construction firms determine appropriate goals for their organizations by considering their strengths and weaknesses together with the opportunities and threats introduced by the sector,

(ii) These goals indicate construction firms' strategic tendencies and thereby can be used to classify them.

These arguments reflect the main focus of this paper. In this context, current positions of 50 large-scale construction firms were defined by means of a SWOT analysis, and then, these positions' correlation with firms' primary goals was examined. Finally, firms were grouped according to Miles and Snow's Strategy Typology.

\section{Methodology}

In the present study, it was aimed to determine strategy groups of construction firms operating in Turkey according to Miles and Snow's Strategy Typology. Toward this aim, Turkish Contractors Association (TCA) which has currently 152 members was contacted. All the members of TCA are large-scale firms of which business volume encompasses nearly $70 \%$ of all domestic and $90 \%$ of all international construction projects done by Turkish contractors. Out of 152 firms, 50 firms agreed to take part in the study. This sample size is statistically large enough $(n=50>30)$ to represent the whole.

For data collection, a questionnaire that consists of four parts was prepared. In the first two parts, questions were asked to obtain general information about firms and to identify their current positions compared to their competitors. For this comparison, answers were scaled as "below average", "average", and "above average". In fact, these two parts were prepared to confirm that the chosen firms were large-scale and successful.

In the third part of the questionnaire, it was aimed to determine the main goals of the firms. Miles and Snow's Typology was used to identify these main goals. This typology is one of the widely used typologies in the literature (Ozdemir, 2012). The following four different organization types with different strategies were defined by (Miles et al., 1978):

- Defenders: Organizations that belong to defenders are mainly conservative. In their market, there is not a wide product range, and thus, they try to improve their internal competencies instead of developing new products or searching for new markets. Therefore, in order to maintain or strengthen their positions in a stable market segment (Desarbo et al., 2005), these firms should have two main objectives: (i) to increase their customer diversity and (ii) to increase product quality for outclassing their competitors. In this context, their main goals should be either customer satisfaction or process optimization.

- Prospectors: They have a broad product or market domain compared to defenders. They have also a dynamic environment which leads them to search new products or 
markets. These characteristics make them good at benefiting from opportunities. The main reason behind the fact that these firms search for new product or market is to maximize their own profits. Therefore, the main goal of these firms should be profit maximization.

- Analyzers: This type of organizations is not strong when compared with defenders and prospectors in terms of internal and external factors, respectively. In other words, their main aim is to maintain their market shares. To be defensive against the threats, they should minimize their risks, which, in turn, makes risk minimization their main goal.

- Reactors: These firms are small-scale and mainly do not have any specific strategy, but just try to survive in the market (Desarbo et al., 2005). In this study, only large-scale construction firms were surveyed, and therefore, this strategy group was not taken into account.

In the last part, a SWOT analysis was prepared to evaluate the firms' organizational structures and current positions in the market. SWOT analysis depends both on the purpose of utilizing it and on the environment where it is utilized. Therefore, in order to develop an effective SWOT analysis, especially external factors which change from region to region should be examined carefully, and regionspecific opportunities and threats should be determined. In general, management ability, financing ability, marketing skills, labor capacity, and experience of an organization constitutes the internal factors while politics, economics, and market size constitutes the external factors of a SWOT analysis. In this context, after a detailed literature review and investigation of Turkey-specific factors, a SWOT analysis that consists of 31 factors was prepared (Table 1). Each factor was organized on a 5-point Likert-scale where 1 and 5 represented "absolutely disagree" and "absolutely agree", respectively.

After the questionnaire was prepared, respondents of 50 firms were visited in their offices, and the questionnaire was applied face-to-face and recorded. During the interviews, necessary interventions were made, and thus, all questionnaire results were used in the statistical analysis.

The reliability of the questionnaire was tested by the Test of Internal Consistency. The Cronbach's Alpha Reliability Test is the commonly used method to evaluate the internal consistency. The Cronbach's alpha coefficient ranges between 0 and 1 , and it is accepted that a value between 0,60 and 0,90 makes a questionnaire reliable. Similarly, the validity of the questionnaire was confirmed by exploratory factor analysis. The Kaiser-Meyer-Olkin test and the Bartlett test of sphericity are preliminary tests used to evaluate the suitability of data for factor analysis. In addition, to determine the strategic groups of the firms, the correlation between SWOT analysis results and the main goal of each firm should be examined. However, 31 factors of the SWOT analysis would complicate and prolong this examination. Therefore, the exploratory factor analysis was also employed to reduce the number of factors to be examined.

In the last stage of the study, it was aimed to classify the firms according to their strategy groups. For this purpose, firms with the same main goals were grouped, and their SWOT analysis results were compared to find a correlation between them.
Table 1

SWOT analysis questions and their codes

\begin{tabular}{|c|l|}
\hline Codes & Questions \\
\hline S 1 & Cheap material supply \\
\hline S 2 & Compliance with the sector \\
\hline S 3 & Reliability in the sector \\
\hline S 4 & Qualified staff \\
\hline S 5 & Experienced managerial staff \\
\hline S 6 & Labor force \\
\hline S 7 & Benchmarking \\
\hline S 8 & Political support \\
\hline S 9 & Financial capability \\
\hline S 10 & Product quality \\
\hline S 11 & Establishing joint venture \\
\hline W 1 & Lack of experience \\
\hline W 2 & Lack of financial solutions \\
\hline W 3 & Lack of design and technical experience \\
\hline W 4 & Wrong choice of investments \\
\hline W 5 & Hang back to specific targets \\
\hline O 1 & Improvement of international construction market \\
\hline O 2 & Openness to global construction market \\
\hline O 3 & Having foreign partners \\
\hline O 4 & Free land allocation \\
\hline O 5 & Exemption from tax \\
\hline O 6 & Incentive premium \\
\hline O 7 & Technological improvements \\
\hline T 1 & Difficulties in getting permits \\
\hline T 2 & Competitive environment of the global construction market \\
\hline T 3 & $\begin{array}{l}\text { Operating in an industry that offers heavily integrated } \\
\text { services }\end{array}$ \\
\hline T 4 & Competitive environment for qualified staff \\
\hline T 5 & Economic uncertainty \\
\hline T 6 & Political uncertainty \\
\hline T 7 & Capital gain of currency \\
\hline T 8 & Economic crisis \\
\hline & \\
\hline
\end{tabular}

\section{Results and Discussions}

\section{General information about the firms and their competitive positions}

Ages of the firms were categorized into three groups, and the results are illustrated in Figure 1. As can be seen in Figure 1, most of the firms have been operating for longer than 15 years. This confirms that they are well-established. In addition, the firms stated that they employ at least 300 employees, which also confirms that they are large-scale enterprises. Figure 2 shows the compared market share sizes of the firms. According to Figure 2, it can be asserted that these firms are influential players in the construction industry.

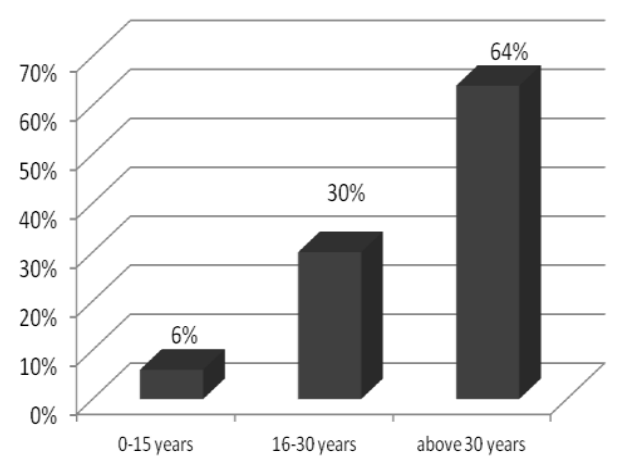

Figure 1. Ages of the firms 


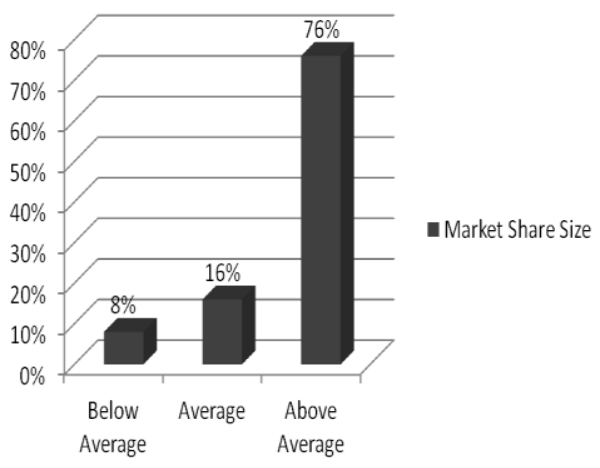

Figure 2. Compared market share sizes of the firms

The rest of the questions and their results are presented in Figures 3-6. These reveal two main results:

1. Most of the surveyed firms have an average or better position when compared with their competitors in the industry. This confirms that the sample universe is relevant to the research.

2. Firms have achieved their goals, which indicates that they have a strategy (i.e., the expected sale and overall sale results are close to each other, or customer satisfaction and manufacturing and delivery speed results are close to each other).

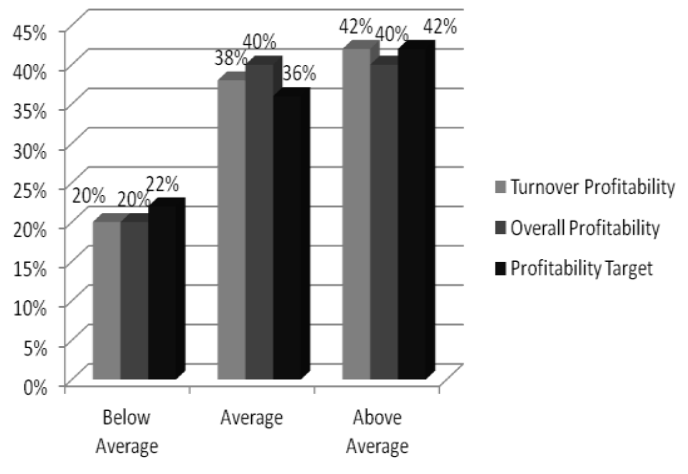

Figure 3. Compared profitability of the firms

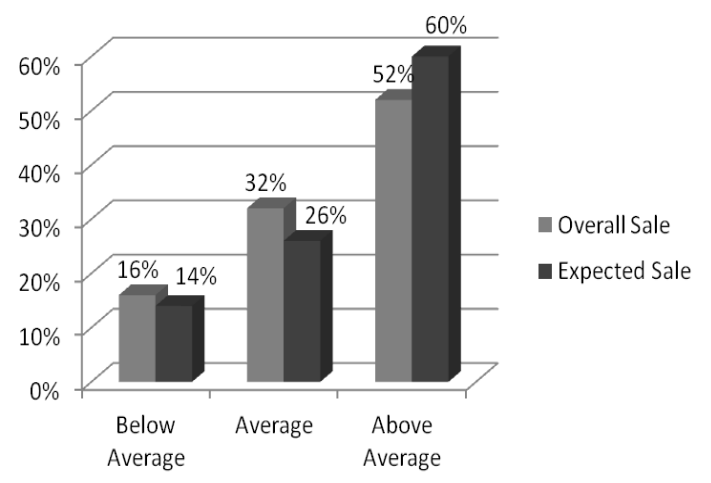

Figure 4. Compared sale targets of the firms

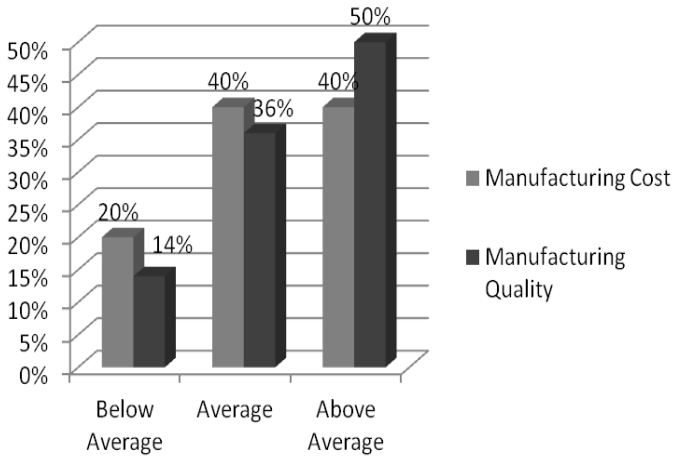

Figure 5. Compared manufacturing cost and manufacturing quality

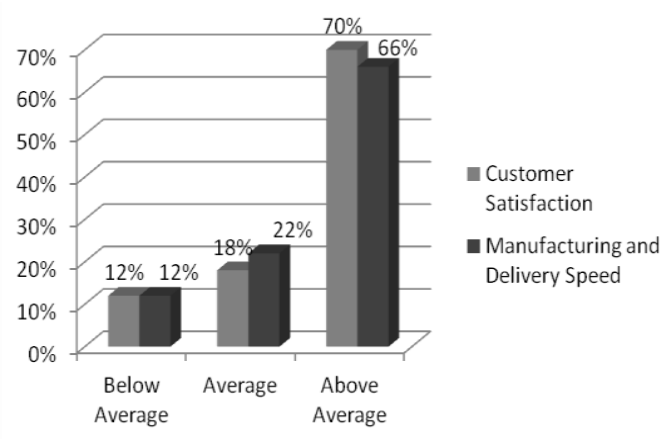

Figure 6. Compared customer satisfaction and manufacturing and delivery speed of the firms

\section{SWOT analysis result}

The Cronbach's alpha coefficient for this questionnaire was found out as 0,891 which is in the accepted interval and makes the questionnaire reliable. In addition, the reliability of each sub-dimension (strengths, weaknesses, opportunities, and threats) of the SWOT analysis was also tested. The results revealed that all of the sub-dimensions are also reliable with a Cronbach's alpha values 0,892 , $0,747,0,869$, and 0,871, respectively. Similarly, the KaiserMeyer-Olkin test $(0,637>0,600)$ and the Bartlett test of sphericity $(0,00<0,05)$ results showed that the obtained values are also appropriate for factor analysis.

Since the SWOT analysis has four sub-dimensions, it was expected that four factor groups would be extracted after the factor analysis. However, the opposite pattern of the factors related with strengths and weaknesses created a high correlation. Therefore, these factors were grouped under the same factor group which was called as competency in this study. As a result, three factor groups (competency, opportunities, and threats) were obtained to represent 31 factors, and these account for $62,78 \%$ of the variance (Table 2). 
Table 2

Factor analysis results

\begin{tabular}{|c|c|c|c|}
\hline & \multicolumn{3}{|c|}{ Factors } \\
\hline 号 & 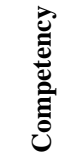 & $\begin{array}{l}\overrightarrow{\mathrm{J}} \\
\vec{E}\end{array}$ & 壱 \\
\hline Cheap material supply & $\mathbf{0 , 8 1 0}$ & & \\
\hline Labor force & 0,761 & & \\
\hline Product quality & 0,748 & & \\
\hline Experienced managerial staff & $\mathbf{0 , 7 1 9}$ & & \\
\hline Reliability in the sector & 0,704 & & \\
\hline Lack of financial solutions & $\mathbf{0 , 7 0 1}$ & & \\
\hline Qualified staff & 0,689 & & \\
\hline Lack of experience & 0,688 & & \\
\hline Establishing joint venture & 0,624 & & \\
\hline Financial capability & 0,615 & & \\
\hline $\begin{array}{l}\text { Lack of design and technical } \\
\text { experience }\end{array}$ & 0,598 & & \\
\hline Compliance with the sector & 0,596 & & \\
\hline Political support & $\mathbf{0 , 5 8 5}$ & & \\
\hline Hang back to specific targets & $\mathbf{0 , 5 4 3}$ & & \\
\hline Wrong choice of investments & $\mathbf{0 , 5 1 1}$ & & \\
\hline Benchmarking & 0,506 & & \\
\hline $\begin{array}{l}\text { Competitive environment of the } \\
\text { global construction market }\end{array}$ & & $\mathbf{0 , 8 0 7}$ & \\
\hline Difficulties in getting permits & & 0,791 & \\
\hline Capital gain of currency & & 0,748 & \\
\hline $\begin{array}{l}\text { Operating in an industry that } \\
\text { offers heavily integrated services }\end{array}$ & & $\mathbf{0 , 7 2 9}$ & \\
\hline Political uncertainty & & 0,708 & \\
\hline Economic crisis & & 0,626 & \\
\hline $\begin{array}{l}\text { Competitive environment for } \\
\text { qualified staff }\end{array}$ & & 0,601 & \\
\hline Economic uncertainty & & 0,565 & \\
\hline $\begin{array}{l}\text { Openness to global construction } \\
\text { market }\end{array}$ & & & $\mathbf{0 , 8 2 6}$ \\
\hline $\begin{array}{l}\text { Improvement of international } \\
\text { construction market }\end{array}$ & & & 0,756 \\
\hline Incentive premium & & & $\mathbf{0 , 7 4 7}$ \\
\hline Exemption from tax & & & 0,744 \\
\hline Free land allocation & & & 0,676 \\
\hline Technological improvements & & & 0,668 \\
\hline Having foreign partners & & & 0,646 \\
\hline
\end{tabular}

\section{Determining the Strategy Groups of the Firms}

In order to determine strategy groups, the firms with same main goals were grouped, and for each group a table was established. Each table included the mean values together with their normalized states of competency $(\mathrm{C})$, threats $(\mathrm{T})$, and opportunities $(\mathrm{O})$ factor groups obtained by the SWOT analysis. In Table 3, the table established for examining the risk minimization is shown. After establishing similar tables for each main goal, the average values were compared, and as a result, three different firm profiles were identified (Table 4).

Firms with main goals "process optimization" and "customer satisfaction" had a higher average value of competency when compared with other firms. This indicates that they are more competent. However, the average value of opportunities was lower than that of profit maximization group firms. In other words, these firms are not good at making use of opportunities. Therefore, these firms were grouped under defenders.
The second group with the main goal "profit maximization" had a significantly higher average value of opportunities when compared with other groups. This result reveals that these firms are open for new markets and good at making use of new opportunities. As a result, these firms were accepted as prospectors.

Finally, the average value of each factor of the last group with the main goal "risk minimization" was lower than the other groups' values. Namely, they are weak at making use of opportunities when compared with their competitors, but very defensive against threats. Therefore, these firms were grouped under analyzers.

Table 3

Table established for examining the risk minimization

\begin{tabular}{|c|c|c|c|c|c|c|}
\hline Firm & C & T & O & $\begin{array}{c}\text { Normalized } \\
\text { C }\end{array}$ & $\begin{array}{c}\text { Normalized } \\
\text { T }\end{array}$ & $\begin{array}{c}\text { Normalized } \\
\text { O }\end{array}$ \\
\hline 5 & 2,54 & 3,05 & 2,78 & $50,80 \%$ & $61,00 \%$ & $55,60 \%$ \\
\hline 12 & 3,45 & 2,85 & 2,34 & $69,00 \%$ & $57,00 \%$ & $46,80 \%$ \\
\hline 18 & 2,67 & 1,74 & 2,63 & $53,40 \%$ & $34,80 \%$ & $52,60 \%$ \\
\hline 26 & 2,39 & 1,94 & 3,41 & $47,80 \%$ & $38,80 \%$ & $68,20 \%$ \\
\hline 37 & 3,37 & 1,75 & 2,81 & $67,40 \%$ & $35,00 \%$ & $56,20 \%$ \\
\hline 45 & 4,02 & 1,42 & 3,95 & $80,40 \%$ & $28,40 \%$ & $79,00 \%$ \\
\hline 49 & 2,73 & 2,16 & 2,26 & $54,60 \%$ & $43,20 \%$ & $45,20 \%$ \\
\hline & & Min. & $47,80 \%$ & $28,40 \%$ & $45,20 \%$ \\
\cline { 2 - 7 } & Max. & $80,40 \%$ & $61,00 \%$ & $79,00 \%$ \\
\cline { 2 - 7 } & Avg. & $\mathbf{6 0 , 4 9 \%}$ & $\mathbf{4 2 , 6 0 \%}$ & $\mathbf{5 7 , 6 6 ~ \%}$ \\
\cline { 3 - 7 } & & & & &
\end{tabular}

Table 4

Strategic profiles of the surveyed construction firms

\begin{tabular}{|c|c|c|}
\hline $\begin{array}{c}\text { Miles \& } \\
\text { Snow's } \\
\text { Strategy } \\
\text { Typology }\end{array}$ & Features & Goals \\
\hline \multirow{2}{*}{$\begin{array}{l}\text { Defenders } \\
\text { Type } 1\end{array}$} & $\begin{array}{l}\text { Strong when compared with their } \\
\text { competitors; }\end{array}$ & Process optimization; \\
\hline & $\begin{array}{l}\text { Leery in making use of } \\
\text { opportunities; }\end{array}$ & $\begin{array}{l}\text { Customer } \\
\text { satisfaction; }\end{array}$ \\
\hline \multirow{2}{*}{$\begin{array}{l}\text { Prospectors } \\
\text { Type } 2\end{array}$} & Moderately strong; & \multirow[b]{2}{*}{ Profit maximization; } \\
\hline & $\begin{array}{l}\text { Good at making use of new } \\
\text { opportunities. }\end{array}$ & \\
\hline \multirow[t]{3}{*}{$\begin{array}{l}\text { Analyzers } \\
\text { Type } 3\end{array}$} & $\begin{array}{l}\text { Weak when compared with their } \\
\text { competitors; }\end{array}$ & \multirow{3}{*}{ Risk minimization. } \\
\hline & Close to improvements; & \\
\hline & Very defensive against threats. & \\
\hline
\end{tabular}

\section{Conclusions}

Strategy can simply be defined as a path which a firm follows to achieve its goals and stays in the market. Especially in highly competitive markets, strategies determine if a firm will survive. Therefore, strategic management plays a crucial role in a firm's management process.

The construction industry is very sensitive to its dynamic environment. Any change in the environment may affect firms positively or negatively. In addition, the industry is also highly competitive. Therefore, every firm should have specific strategies to cope with or take advantage of these changes.

Although, the importance of strategic management is recognized by the construction industry, it is rarely utilized among construction firms in Turkey (Kazaz \& Ulubeyli, 2009). On the other hand, in this study it was argued that every firm has some specific goals and that they try to 
achieve these goals in a formal or informal way. This confirms that they have also a strategy. Therefore, determining the strategy group of a firm will be the first step for adapting strategic management to a firm's organization. Knowing the strategy group will help a firm to identify appropriate strategies to maintain in the group or to change the group.

In this context, a methodology was first developed, and then, 50 large-scale construction firms operating in Turkey were surveyed and classified according to their strategy groups. Toward this aim, the respondents were asked to select one of the presented goals as their primary target. Then, a SWOT analysis was applied to each construction firm to evaluate its current position, and the results were evaluated. The results denoted that there is a high correlation between the firms' current positions and their goals. In addition, the characteristics of the surveyed firms were appropriate to be categorized as defenders, prospectors, and analyzers, according to Miles and Snow's Strategy Typology. In other words, the surveyed firms have similar strategic tendencies with the strategic groups defined by Miles et al., (1978).

\section{Acknowledgements}

The authors gratefully acknowledge the top managers of the surveyed firms for their generous collaboration and contributions. The authors also thank the financial supports provided by the Committees on Research Grants of Akdeniz University and Bulent Ecevit University.

\section{References}

Abu Bakar, A. H., Tufail, M. A., Yusof, M. N., \& Virgiyanti, W. (2011). Implementation of Strategic Management Practices in the Malaysian Construction Industry. Pakistan Journal of Commerce and Social Sciences, 5, 140-154.

Anthony, R. N. (1965). Planning and Control Systems, a Framework for Analysis. Harvard University Press, Boston, MA., 180.

Arif, F., Azhar, N., \& Bayraktar, M. E. (2012). Strategic Management Concepts and Practices in Pakistan: A Construction Industry Perspective. Construction Research Congress 2012, 1530-1539. http://dx.doi.org/10.1061/9780784412 329.154

Betts, M., \& Ofori, G. (1992) Strategic planning for competitive advantage in construction. Construction Management and Economics, 10, 511-532. http://dx.doi.org/10.1080/01446199200000049

Byars, L. L. (1987). Strategic Management Planning and Implementation, Concepts and Cases. Second Edition, Harper \& Row Publishers: New York, 940.

Chandler, A. D. (1962). Strategy and Structure: Chapters in the History of the Industrial Enterprise. The Mit Press: London., 463.

Cheah, C. Y. J., \& Garvin, M. J. (2004). An open framework for corporate strategy in construction. Engineering, Construction and Architectural Management, 11, 176-188. http://dx.doi.org/10.1108/09699980410535787

Cheah, C. Y. J., Garvin, M. J., \& Miller, J. B. (2004). Empirical Study of Strategic Performance of Global Construction Firms. Journal of Construction Engineering and Management, 130, 808-817. http://dx.doi.org/10.1061/(ASCE)07339364(2004)130:6(808)

Chinowsky, P. S., \& Meredith, J. E. (2000). Strategic Management in Construction. Journal of Construction Engineering and Management, 126, 1-9. http://dx.doi.org/10.1061/(ASCE)0733-9364(2000)126:1(1)

Danosh, A. (2005). Strategic planning practice of construction firms in Ghana. Construction Management and Economics, 23, 163-168. http://dx.doi.org/10.1080/0144619042000241435

Desarbo, W. S., Di Benedetto, C. A., Song, M., \& Sinha, I. (2005). Revisiting the Miles and Snow Strategic Framework: Uncovering Interrelationships Between Strategic Types, Capabilities, Environmental Uncertainty, and Firm Performance. Strategic Management Journal, 26, 47-74. http://dx.doi.org/10.1002/smj.431

Dikmen, I., \& Birgonul, M. T. (2003). Strategic Perspective of Turkish Construction Companies. Journal of Management in Engineering, 19, 33-40. http://dx.doi.org/10.1061/(ASCE)0742-597X(2003)19:1(33)

Drucker, P. F. (1999). Management Challenges for the 21 st Century. HarperCollins Publishers, 1st Edition, Burlington, 171.

Gelinier, O. (1986). Strategie de l'Entreprise et Motivation des Hommes. Editions Hommes et Techniques: Paris, 312.

Gray, D. H. (1986). Uses and Misuses of Strategic Planning. Harvard Business Review.

Hill, C. W. L., \& Jones, G. R. (1995). Strategic Management Theory, an Integrated Approach. Houghton Mifflin Company, Third Edition: Boston, 511.

Hofer, C. W., \& Schendel, D. (1978). Strategy Formulation: Analytical Concepts, West Publishing Company: Minnesota, 234.

Kazaz, A., \& Ulubeyli, S. (2009). Strategic Management Practices in Turkish Construction Firms. Journal of Management in Engineering, 25, 185-194. http://dx.doi.org/10.1061/(ASCE)0742-597X(2009)25:4(185)

Lynch, R. (2003). Corporate Strategy. Financial Times Prentice Hall, Third Edition: Harlow. 830.

Male, S., \& Stocks, R. (1991). Competitive advantage in construction. Butterworth-Heinemann, Stoneham, Mass. 479 
Miles, R. E., Snow, C. C., Meyer, A. D., \& Jr. Coleman, H. J. (1978). Organizational Strategy, Structure, and Process. The Academy of Management Review, 3, 546-562. http://dx.doi.org/10.2307/257544

Mintzberg, H., \& Quinn, J.B. (1996). The Strategy Process Concepts, Contexts, Cases, Prentice-Hall İnc., London. 489.

Naaronaja, M., Haapalainen, P., \& Lonka, H. (2007). Strategic management tools in projects case construction project. International Journal of Project Management, 25, 659-665. http://dx.doi.org/10.1016/j.ijproman.2007.04.002

Ozdemir, B. E. (2012). Strategy Determination in Construction Industry by Using Fuzzy Method, Akdeniz University Institute of Science (in Turkish), 106.

Porter ME. (1980). Competitive Strategy: Techniques for Analyzing Industries and Competitors. Free Press: New York.

Price, A. D. F., Ganiev, B. V., \& Newson, E. (2003). Changing strategic management practice within the UK construction industry. Strategic Change, 12, 347-366. http://dx.doi.org/10.1002/jsc.649

Price, A. D. F., \& Newson, E. (2003). Strategic Management: Consideration of Paradoxes, Processes, and Associated Concepts as Applied to Construction. Journal of Management in Engineering, 19, 183-192.

http://dx.doi.org/10.1061/(ASCE)0742-597X(2003)19:4(183)

Quinn, J. B., Mintzberg, H., Lampel, J., \& Ghoshal, S. (2003). The Strategy Process Concepts, Contexts, Cases. Prentice Hall, Fourth Edition: New Jersey, 480.

Venegas, P. (1997). A methodology to analyze strategies and policies in the construction industry, PhD thesis, Dept. of Constr. Engrg. And Mgmt., Catholic Univ. of Chile, Chile (in Spanish).

Warszawski, A. (1996). Strategic Planning in Construction Companies. Journal of Construction Engineering and Management, 122, 133-140. http://dx.doi.org/10.1061/(ASCE)0733-9364(1996)122:2(133)

Yisa, S., \& Edwards, D. J. (2002). Evaluation of business strategies in the UK construction engineering consultancy. Measuring Business Excellence, 6, 23-31. http://dx.doi.org/10.1108/13683040210420754

The article has been reviewed.

Received in March, 2013; accepted in April, 2015. 